\title{
Technical Analysis of VTOL UAV
}

\author{
Seunghee Yu, Jinyeong Heo, Sekyung Jeong, Yongjin Kwon* \\ Department of Industrial Engineering, Ajou University, Suwon, South Korea \\ Email: *yk73@ajou.ac.kr
}

How to cite this paper: Yu, S., Heo, J., Jeong, S. and Kwon, Y. (2016) Technical Analysis of VTOL UAV. Journal of Computer and Communications, 4, 92-97. http://dx.doi.org/10.4236/jcc.2016.415008

Received: August 25, 2016

Accepted: November 25, 2016

Published: November 28, 2016

\begin{abstract}
Overall, this paper explains the related information about VTOL and trend of this technology worldwide. Also, it comes up with the distinction among VTOL and helicopter and fixed wing aircraft. This paper concentrates on domestic and international drones that utilize VTOL technology. Also, this paper gives the explanation about VTOL's performance and object. Furthermore, this paper predicts the future of VTOL and which area this technology going to be used.
\end{abstract}

\section{Keywords}

VTOL, UAV, Tilt-Rotor, Multicopter, Military

\section{Introduction}

Currently, the demand for VTOL, which can manage vertical takeoff and landing is increasing. VTOL is developed in the form of combining benefits of both multicopter and fixed wing aircraft. Multicopter can do vertical takeoff and landing but its rotary wing rotor can't pass the velocity of sound However, aircraft can go faster but it needs airstrip for strong lift. VTOL, which is possible to high speed vertical takeoff and landing is developed by many countries for the purpose of the defense industry. But its development focused on some countries like Korea, Japan, France, Swiss, China, etc. Because of the limitation of latest technology and also its problem in industrial utilization. VTOL can do various functions in various industries...VTOL can do High-resolution photography and it can combine with smartphones. And it can control forest, on the water, traffic situation and the site of the accident. Also it can escort ships by military purposes. In this way, this study analyzes the level of technologies of VTOL and its global trends [1] [2] [3].

\section{Case Study}

Most countries are promoting briskly UAV development from military tilt-rotor based 
in small unmanned aircraft and this military conversion development is making actively so some countries are already using UAV in the actual fight. While grasping the VTOL development examples, we want to identify the fact that each country developed technologies in any direction. In this article, let's look at the VTOL developments of 7 countries such as South Korea, Japan, Israel, France, Switzerland, China, and the United States [4] [5] [6].

\subsection{Kus-TR (TR-60) \& TR-100}

Kus-TR is a VTOL developed by Korean Air in South Korea. This UAV is one of the world's first VTOL UAV that Korea developed by their own technologies. Korea Air is the company of air transport business that established routes from Korea for passenger and cargo traffic. It also has been in aerospace business which is studying aircraft design and production, civil and military aircraft maintenance and satellites etc. Korean Air and KARI (Korea Aerospace Research Institute) co-produce KUS-TR. They succeeded initial flight in 10 May 17, 2013 and they aim to the world's first commercialization in 2010. Because it is made small and light compared to the TR-100, it seems to be easy to move through the vehicle. TR-100 is a VTOL Smart UAV for civilian that was developed as a way of tilt-rotor by KARI (Figure 1, Table 1 and Table 2).

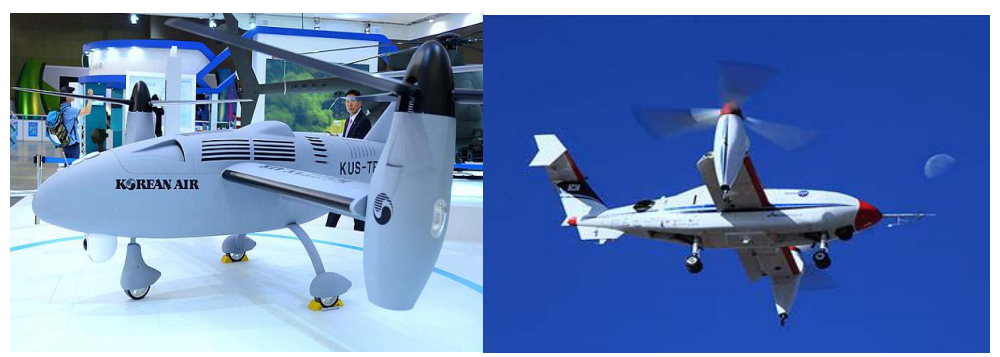

Figure 1. KUS-TR \& TR-100.

Table 1. KUS-TR performance \& data.

\begin{tabular}{cccc}
\hline Full length & $3.5 \mathrm{~m}$ & Overall width & $5.2 \mathrm{~m}$ \\
Maximum weight & $210 \mathrm{~kg}$ & Weight on board & $30 \mathrm{~kg}$ \\
Engine & 55 horse power & Maximum speed & $250 \mathrm{~km} / \mathrm{h}$ \\
Cruising speed & $200 \mathrm{~km} / \mathrm{h}$ & Maximum altitude & $4.5 \mathrm{~km}$ \\
Management radius & $60-200 \mathrm{~km}$ & Time in service & $6 \mathrm{hrs}$ \\
Manufacturer & Korean Air & Development nation & South Korea \\
\hline
\end{tabular}

Table 2. TR-100 performance \& data.

\begin{tabular}{cccc}
\hline Full length & $5 \mathrm{~m}$ & Overall width & $7 \mathrm{~m}$ \\
Maximum weight & $1000 \mathrm{~kg}$ & Weight on board & $100 \mathrm{~kg}$ \\
Engine & PWC-206(56HP) & Maximum speed & $500 \mathrm{~km} / \mathrm{h}$ \\
Fuel level & $300 \mathrm{~kg}$ & Time in service & $5 \mathrm{hrs}$ \\
Management radius & $200 \mathrm{~km}$ & Price & 30hundred million won \\
Manufacturer & KARI & Development nation & South Korea \\
\hline
\end{tabular}




\subsection{Aerosense}

Aerosense is a high speed VTOL UAV developed by Japan's SONY. They developed industrial system combining the UAV and the cloud technology and will soon launch a product on a commercial UAV market. Aerosense is light and flying at a low rate compared to other VTOL, but is expected to be used in conjunction with emerging services. It provides several industrial services such as delivery, patrol, shooting and etc. and is equipped with a high-quality shooting, Cloud uploading technology as a high- speed VTOL UAV. It is also possible to provide aerial photography data analysis services in the industry with combination of high-speed autonomous flight technolo- gies and smartphone technology (Table 3).

\subsection{Air-Mule}

Air Mule is a UAV for Israel developed by Tactical Robotics Inc. Tactical Robotics is a UAV manufacturer that developed UAV for military loading called AirMule and now is in the VTOL development what is called Metro Skyways. Air Mule is a massive loading UAV improved the limits that less loading weight for existing VTOL UAV. It has higher speed than other UAVs, so it is expected that high utilization. Also, this UAV is possible to fly by remote control or autonomous flight system (Table 4).

\subsection{Airbus DS Tanan 300}

Airbus DS Tanan300 is a VTOL that is being co-developed by DCNS Inc. of France state-owned shipbuilders and AirbusDS Inc. Airbus Inc. is developing TANAN which can employ aircrafts on the shipboard with cooperation with DCNS Inc. It seems to practice the initial flight of TANAN300 in end of 2016 or early in 2017. Airbus DS TANAN300 has extremely large operational radius around $300 \mathrm{~km}$ because it operates with ship at sea. France is supposed to product additional midrange frigate in the 4000-ton class that can employ TANAN UAV (Table 5).

Table 3. Aerosense performance \& data.

\begin{tabular}{cccc}
\hline Maximum weight & $10 \mathrm{~kg}$ & Weight on board & $10 \mathrm{~kg}$ \\
Time in service & $2 \mathrm{hrs}$ & Maximum speed & $170 \mathrm{~km} / \mathrm{h}$ \\
Manufacturer & Sony & Development nation & Japan \\
\hline
\end{tabular}

Table 4. Air mule performance \& data.

\begin{tabular}{cccc}
\hline Full length & $6.2 \mathrm{~m}$ & Overall width & $3.5 \mathrm{~m}$ \\
Maximum weight & $1000 \mathrm{~kg}$ & Weight on board & $453 \mathrm{~kg}$ \\
Engine & Ariel2 hybridturob shaft & Maximum speed & $414 \mathrm{~km} / \mathrm{h}$ \\
Management radius & $50 \mathrm{~km}$ & Maximum altitude & $5.5 \mathrm{~km}$ \\
Manufacturer & Tactical Robotics & Development nation & Israel \\
\hline
\end{tabular}


Table 5. Airbus DS tanan 300 performance \& data.

\begin{tabular}{cccc}
\hline Full length & $4.3 \mathrm{~m}$ & Overall width & $5 \mathrm{~m}$ \\
Maximum weight & $350 \mathrm{~kg}$ & Weight on board & $80 \mathrm{~kg}$ \\
Engine & Diesel engine & Maximum speed & $150 \mathrm{~km} / \mathrm{h}$ \\
Management radius & $200 \mathrm{~km}$ & Maximum altitude & $4000 \mathrm{~m}$ \\
Manufacturer & Airbus Defense \& Space & Development nation & France \\
\hline
\end{tabular}

\subsection{Wingtra}

Wingtra (Fixed Wing Drone) is being developed in Wingtra Co., Switzerland. Winqtra is a vertical takeoff-landing VTOL which can load regardless of sensor range. Winqtra Co. is a venture company which is divided by the autonomous system laboratory in the Swiss Federal Institute of Technology Zurich. And it is planning to commercialize the latest hybrid Winqtra unmanned planes since 2017.This unmanned plane is manufactured to be able to look after forests. It is suitable to Swiss, which has many forests (Table 6).

\subsection{VD200}

VD200 is a vertical takeoff and landing aircraft developed by CARDI Co, China. CARDI set up a goal of aerospace industry sales to more than 500 billion yuan by 2017 and developing a reconnaissance UAV which is going to be used in future industry. CARDI VD200 has optical and laser designator payload, and ground transportation version is paired with command and control vehicle being transferred by transport vehicle. This UAV, compared to other drone operations, radius of processing, weight, speed is not very good, but not left behind and above average (Table 7).

\subsection{X-Plane}

$\mathrm{X}$ plane is next-generation unmanned vertical takeoff and landing, and it is under development of Defence Advanced Research Projects Agency (DARPA). X-Plane protesting airframe and its initial flight are expected to be done in 2018. X-plane has heavy weight and its engine and speed are by far compared to than the other UAV. Accordingly, it is most likely to be used in the army and play an important role without war casualties in a situation. In the case of Commercial airplanes, Wings is fixed to the fuselage, whereas X-plane put rotary vane in wing so it can supplement its existing shortcomings (Table 8).

\section{Analysis}

Case of the above use the method of tilt rotor, which technology changes the angle of the rotor so that it can take off and land vertically. It is normally used in large airframe like air carrier rather than small airframe like combat plane. Tilt rotor has 2 rotors so its disk load is generally larger that helicopter, which has 1 main rotor. Also, if it is hovering, rotor's downwash clash with wings and reduce its thrust effectiveness. But two 
Table 6. Wingtra performance \& data.

\begin{tabular}{cccc}
\hline Weight on board & $1.5 \mathrm{~kg}$ & Maximum speed & $100 \mathrm{~km} / \mathrm{h}$ \\
Manufacturer & Wingtra & Development nation & Switzerland \\
\hline
\end{tabular}

Table 7. VD200 performance \& data.

\begin{tabular}{cccc}
\hline Full length & $1.8 \mathrm{~m}$ & Overall width & $4.6 \mathrm{~m}$ \\
Maximum weight & $200 \mathrm{~kg}$ & Weight on board & $20 \mathrm{~kg}$ \\
Time in service & $3 \mathrm{hrs}$ & Maximum speed & $260 \mathrm{~km} / \mathrm{h}$ \\
Management radius & $150 \mathrm{~km}$ & Maximum altitude & - \\
Manufacturer & CARDI & Development nation & China \\
\hline
\end{tabular}

Table 8. X-plane performance \& data.

\begin{tabular}{cccc}
\hline Full length & $15.2 \mathrm{~m}$ & Overall width & $13.4 \mathrm{~m}$ \\
Maximum weight & More than $5450 \mathrm{~kg}$ & Engine & 4000HP engine \\
Time in service & - & Maximum speed & $741 \mathrm{~km} / \mathrm{h}$ \\
Manufacturer & DARPA \& Aurora Flight Science & Development nation & USA \\
\hline
\end{tabular}

rotors that spins in the opposite direction with each other don't need any tail rotor so that much of engine power is saved.

If tilt-rotor perform only slow flight of the helicopter mode, it is somewhat lacking in low-speed performance besides helicopter. But, it can fly at altitudes more than twice of the helicopter and produce twice of the cruising speed. Therefore, it seems to be used a lot when it should go to a higher area or move faster. In the case of TR-60, its maximum speed is $250 \mathrm{~km}$ and it can increase up the altitude to a maximum $4 \mathrm{~km}$. In addition, it can fly up to 6 hours in the sky. So, it is expected to be able to play a role about watching, searching, reconnaissance and etc. in large area. Also TR60 can be used in the construction industries which deliver construction supplies without cranes.

\section{Conclusion}

VTOL is a different purpose depending on the weight, weight, operating radius, speed. Most of them are made by the military, but it seems to be endless use cases are used in a variety of markets. For example, the FE-Panther detects forest fires and illegal fishing, even safety of such operations is to detect fish. It can also be reported to the state road, highway reconnaissance, traffic conditions bring the real-time location information. Aerosense is an autonomous flight and also provides analysis of the data taken from public necessities of industry. In addition, the role seems to be used for purposes such as transportation, forestry, transport of large-scale products. But until the commercialization, you go through the process such reliability testing, system development on the part of the test aircraft (prototype). When you see the United States' Belsa that made tilt-rotor aircraft, aircraft tilt-rotor is very difficult to develop a practical aircraft. But 
for a long time, so that made this aircraft is that it's well worth it. By downsizing the size, it can precise and safe landing though a confined area landing and bad weather and also can reduce operating costs. Above all there is no damage of human life, it can perform a variety of military missions, including reconnaissance surveillance, armed attacks, relay communications, and electronic warfare is the biggest advantage. Europe started to develop tilt-rotor to prevent exclusivity of VTOL market in the United States. China announced that it has begun developing a large aircraft tilt-rotor than the V22. South Korea was also promoting the development of tilt-rotor UAV to national projects. Also, Japan and Israel is known to have purchased a V22 to strengthen national defense. Now, globally helicopters having a low survival are now leaving, VTOL expects to take up room in the future. Because VTOL has a lot of efficiency. Therefore, this VTOL development of many countries around the world is expected to be under acceleration. Not only VTOL can be used to the role of military but also leverage in private for fire surveillance, reconnaissance mapping. In the domain of remote sensing, it will replace estimated satellite significant portion. It seems to be used as a means to effectively monitor the contamination problem for the global warming which has a number of problems in the world.

\section{Acknowledgements}

Following are the results of a study on the "Leaders INdustry-university Cooperation (LINC)" Project, supported by the Ministry of Education, South Korea.

\section{References}

[1] Cho, A., Yoo, C., Kang, Y. and Park, B. (2014) Heave Motion Estimation of a Ship Deck for Shipboard Landing of a VTOL UAV. Journal of the SOCIETY FOR Aerospace System Engineering, 8, 14-19.

[2] Kim, J., Lee, K., Wang, H., An, J., Park, S., Lee, S., Kim, M. and Han, Y. (2013) Pre-Concept Design Study of VTOL UAV. Sejon University.

[3] Hu, T. and Desai, J.P. (2004) Soft-Tissue Material Properties under Large Deformation: Strain Rate Effect.

[4] Yu, M.H. (2016) Drone of 500km/hrs. Joonangiilbo.

[5] Sheldon (2016) KARI Tiltrotor UAV. http://news.joins.com/article/19495229

[6] Kim, Y. (2012) Balancing of Tiltrotor UAV Rotor System. KSAS. 
Submit or recommend next manuscript to SCIRP and we will provide best service for you:

Accepting pre-submission inquiries through Email, Facebook, LinkedIn, Twitter, etc. A wide selection of journals (inclusive of 9 subjects, more than 200 journals)

Providing 24-hour high-quality service

User-friendly online submission system

Fair and swift peer-review system

Efficient typesetting and proofreading procedure

Display of the result of downloads and visits, as well as the number of cited articles

Maximum dissemination of your research work

Submit your manuscript at: http://papersubmission.scirp.org/

Or contact jec@scirp.org 